\title{
ANALISIS HUBUNGAN PERSEPSI MANFAAT YANG DIRASAKAN TERHADAP KONSISTENSI PENGGUNAAN KONDOM PADA WARIA PEKERJA SEKS DALAM PENCEGAHAN HIV AIDS DI KOTA MAKASSAR
}

\author{
Dian Ardyanti ${ }^{1}$, Antono Suryoputro ${ }^{2}$, Zahroh Shaluhiyah ${ }^{3}$ \\ 1,2,3 Bagian Promosi Kesehatan Fakultas Kesehatan Masyarakat Universitas Diponegoro
}

\begin{abstract}
ABSTRAK
Waria menjadi kelompok dengan risiko tinggi penularan HIV AIDS disebabkan banyaknya daerah pangkalan bagi waria untuk melakukan transaksi seksual dengan pasangan seks.Risiko penularan HIV AIDS besar terjadi pada waria pekerja seks, sehingga untuk mencegah penularan HIV AIDS dapat dilakukan melalui seks yang sehat dengan pemakaian kondom dan pelicin secara rutin dan benar. Perubahan perilaku dikalangan waria pekerja seks masih sangat sulit karena masih rendahnya pemakaian kondom dikalangan waria.Tujuan penelitian adalah menganalisis hubungan persepsi manfaat yang dirasakan dengan konsistensi penggunaan kondom pada Waria Pekerja Seks untuk pencegahan HIV AIDS di kota Makassar.Jenis penelitian ini adalah penelitian mix methods dengan pendekatan kuantitatif dan kualitatif menggunakan desain sequential explanatory (model kombinasi). Teknik pengumpulan data kuantitatif menggunakan desain penelitian cross sectional dan data kualitatif menggunakan wawancara mendalam dengan rancangan penelitian menggunakan studi kasus untuk memperkuat hasil kuantitatif yang diperoleh dari Waria Pekerja Seks yang HIV positif. Jumlah responden dalam penelitian ini sebanyak 60 orang. Hasil penelitian menunjukkan bahwa ada hubungan persepsi manfaat yang dirasakan $(p=0,013)$ dengan konsistensi penggunaan kondom pada Waria Pekerja Seks. Dapat disimpulkan bahwa persepsi manfaat yang dirasakan berhubungan dengan konsistensi penggunaan kondom pada Waria Pekerja Seks untuk pencegahan HIV AIDS.
\end{abstract}

Kata Kunci: Konsistensi, HIV AIDS, Waria Pekerja Seks.

PENDAHULUAN

Acquired Immuno Deficiency

Syndrome merupakan penyakit menular yang disebabkan virus Human Immunodeficiency Virus (HIV).

Penyebarannya sangat cepat ke seluruh dunia. (Ridwan, 2013)

Pandemi AIDS telah menyebar paling sedikit di 166 negara di dunia. Jumlah kasusnya terus meningkat sejak pertama kali ditemukan dikalangan pria homoseksual di Amerika Serikat pada tahun 1981. Hal ini menimbulkan dampak buruk terhadap pembangunan bangsa secara keseluruhan karena selain berpengaruh terhadap kesehatan juga 
terhadap keadaan sosial, ekonomi, politik dan pertahanan keamanan. (UNAIDS,2016)

Berdasarkan hasil penelitian dari National Center for Health Research, di Amerika tahun 2002 sekitar 4,4\% masyarakat yang melakukan hubungan homoseksual dengan usia 15-44 tahun. Berdasarkan hasil statistikdiIndonesia menunjukkan bahwa sekitar 8-10 juta pria pernah terlibat dalam hubungan homoseksual. (Fauzi,2008)

Indonesia merupakan salah satu negara di wilayah Asia dengan pertumbuhan kasus HIV dan AIDS relatif lebih cepat dan termasuk dalam daerah endemis terkonsentrasi (Concentrated Level Epidemic) yang paling berisiko, artinya negara yang mempunyai tingkat prevalensi HIV lebih dari 5\% pada subpopulasi tertentu misalnya pada kelompok penjaja seks dan pada para penguna NAPZA. Sejak kasus pertama yang ditemukan pada tahun 1987 pada seorang wisatawan belanda yang berkunjung dan meninggal di Bali, sampai saat ini kasus baru HIV terus meningkat. Sehingga diperlukan pelaksanaan program yang sesuai dengan jumlah target populasinya agar situasi dan epidemic HIV AIDS yang diperkirakan terus meningkat dapat dikendalikan. (Demartoto,2011)

Berdasarkan data Dinas Kesehatan Kota Makassar tahun 2017, bahwa jumlah penderita HIV AIDS hingga saat ini telah mencapai angka 9.302 orang. Data yang berhasil dikumpulkan oleh KPA kota Makassar dari seluruh rumah sakit, pusat kesehatan masyarakat (Puskesmas) atau layanan konseling lainnya dari bulan Juni 2005 hingga 2017 itu adalah 9.302 orang. Untuk penderita HIV jumlahnya sekitar 6.760 orang dan bagi warga yang sudah positif AIDS sebanyak 2.452 orang. Penyebaran HIV AIDS tiap tahun mengalami perubahan dari melalui jarum suntik kini penyebaran HIV AIDS didominasi oleh pergaulan seks bebas, termasuk hubungan sesama jenis. (Dinkes Kota Makassar,2017)

Berdasarkan distribusi kasus HIV AIDS pada LSM YPKDS terkait faktor risiko tahun 2016 hingga tahun 2017 mencapai 3.568 kasus. Prevalensi HIV AIDS tinggi pada pasangan risti (risiko tinggi) sebesar 10,87\%, diikuti LSL (Lelaki Seks Lelaki) sebesar 7,68\%, pelanggan WPSL sebesar $4,82 \%$, penasun sebesar 4,27\%, pelanggan WPSTL sebesar 2,48\% dan Waria sebesar 1,47\%. Terdapat sebanyak 89 waria di antaranya positif terkena HIV AIDS di tahun 2016 sedangkan pada tahun 2017, kasus HIV AIDS pada waria sebanyak 58. (YPKDS,2017)

Penularan penyakit Infeksi Menular Seksual dan HIV AIDS masih terkonsentrasi pada kelompok dengan risiko tinggi seperti pada waria pekerja seks. Pada tahun 2016, kasus Infeksi Menular Seksual 
(IMS) di kota Makassar sebanyak 2.676 kasus menurut kelompok risiko yang tertinggi adalah kelompok WPS yaitu sebanyak 2024 kasus. Sedangkan, LSL (Lelaki Suka Lelaki) sebanyak 96 kasus, pelanggan PS (Pekerja Seks) 50 kasus, WBP 50 kasus, pasangan risti 44 kasus, waria 9 kasus, dan lain-lain (Bumil, karyawan, tutup status). (Dinkes Kota Makassar, 2017)

Waria menjadi kelompok dengan risiko tinggi penularan HIV AIDS disebabkan banyaknya daerah pangkalan (hospot) bagi waria untuk melakukan transaksi seksual dengan pelanggan sehingga waria dikatakan berisiko terkena HIV AIDS. Secara biologis, semua waria melakukan hubungan seksual melalui anal selama kehidupan seksnya dibandingkan wanita pekerja seks yang hanya 10\% menggunakan seks anal, sehingga hampir $11 \%$ dari transeksual ditemukan positif HIV dari jumlah keseluruhan.(Koes,2014)

Waria yang berdomisili di kota Makassar, umumnya melakukan aktivitas keseharian secara normal, mereka berprofesi dibidang-bidang yang memerlukan keterampilan yang biasa dilakukan wanita. Waria sering tampil apa adanya tanpa menutup-nutupi ciri kewariaan mereka. Walaupun berpakaian laki-laki tetapi gaya bicara dan tingkah laku mereka punya kekhasan seperti wanita. Dulu, waria cenderung tertutup dan malu-malu namun saat ini, waria lebih berperan dan terbuka.(Mutmainnah,2013)

Gaya hidup seksual waria dapat dicerminkan dari seringnya berganti-ganti pasangan, tidak menggunakan kondom atau pengaman serta melakukan anal dan oral seks. Dalam memenuhi kebutuhan seksnya, waria membutuhkan pasangan seksual dan bisa dijadikan pasangan hidup yang biasa mereka sebut sebagai "suami" atau pacar. Namun, penyebutan "suami" atau pacar ini tidak semata-mata karena adanya ikatan yang sah di antara mereka dan tidak ada perbedaan yang mendasar antara "suami" maupun pacar hanya saja jika pacar artinya laki-laki yang hanya menjadi kekasih dan tidak tinggal serumah dengan mereka sedangkan "suami” adalah laki-laki yang juga menjadi kekasih dan tinggal serumah. (Koeswinarno,2004)

Menurut hasil penelitian Ika $\mathrm{H}$. Enggarwati (2015), menyatakan bahwa waria dalam melindungi diri dari HIV AIDS dan mencegah penularan HIV AIDS masih sangat rendah yang disebabkan karena pengetahuan para waria yang menjadi salahsatu kendala mereka dalam melindungi dirinya dari hal-hal yang tidak diinginkan. Perilaku pencegahan penularan HIV AIDS sangat diperlukan ketika berhubungan seksual. Jika upaya pencegahan tidak dilakukan, maka 
dikhawatirkan orang yang terkena infeksi HIV AIDS jumlahnya akan bertambah ditiap tahunnya.(Enggarwati,2015)

Risiko penularan IMS dan HIV AIDS besar terjadi pada waria pekerja seks, sehingga untuk mencegah penularan IMS dan HIV AIDS dapat dilakukan melalui seks yang sehat dengan pemakaian kondom dan pelicin secara tepat dan benar. Perubahan perilaku dikalangan waria pekerja seks masih sangat sulit karena masih rendahnya pemakaian kondom dikalangan waria. Pada penelitian sebelumnya, pemakaian kondom pada waria selama 5 kali berhubungan seks yang terakhir sebanyak $65,9 \%$, tidak pernah pakai kondom atau memakai sekali 7,8\%, memakai kondom 2 kali 14,9\%, memakai kondom 3 kali 2,4\%, dan memakai kondom menaungi mereka. Setiap minggunya, waria pekerja seks memperoleh kondom yang langsung didistribusikan oleh LSM Gaya Celebes dan apabila kondom habis, mereka dapat langsung meminta kepada koordinator waria pekerja seksnya atau LSM Gaya Celebes yang menaungi mereka.

\section{BAHAN DAN METODE}

Penelitian ini menggunakan jenis penelitian mix methods dengan pendekatan kuantitatif dan kualitatif. Penelitian ini menggunakan desain sequential explanatory (kombinasi model) yaitu penelitian yang diawali menggunakan metode kuantitatif dan selanjutnya dengan metode kualitatif. (Sugiyono,2014)

Data kuantitatif menggunakan desain penelitian Cross sectional dengan

Tabel 1. Distribusi Frekuensi Persepsi Manfaat yang dirasakan

\begin{tabular}{llll}
\hline No & Persepsi Manfaat yang dirasakan & $\mathrm{f}$ & $\%$ \\
\hline 1 & Kurang & 11 & 18,3 \\
2 & Baik & 49 & 81,7 \\
\hline Total & & 60 & 100 \\
\hline
\end{tabular}

Sumber: Data Primer, 2018

lebi dari 3 kali 9,9\%.(Nadhofah,2014)

Ketersediaan kondom pada waria pekerja seks tergantung pada kondom yang disediakan oleh KPAP Sul-Sel maupun dari LSM Yayasan Gaya Celebes yang penelitian yang hanya melakukan pengamatan sewaktu yaitu variabel independent dan variabel dependent diukur pada saat yang bersamaan serta dalam satu kali pengukuran.(Sugiyono,2014) 
Sedangkan, data kualitatif dilakukan dengan tujuan untuk menggambarkan atau membuat deskripsi suatu keadaan. Teknik pengumpulan data melalui wawancara mendalam (Indepth Interview) dengan rancangan penelitian menggunakan studi kasus (case study) untuk memperkuat hasil penelitian kuantitatif yang diperoleh dari Waria Pekerja Seks yang HIV positif.

Populasi dalam penelitian kuantitatif ini adalah Waria Pekerja Seks yang terdaftar pada LSM Gaya Celebes sebanyak 60 orang.Sampel yang digunakan dalam penelitian ini adalah semua Waria Pekerja Seks yang terdaftar pada LSM Gaya Celebes sebanyak 60 orang.Dalam penelitian ini, teknik pengambilan sampel menggunakan metode total sampling.Dengan demikian, peneliti mengambil sampel dari seluruh waria yang bekerja sebagai pekerja seks dengan jumlah 60 orang.

Adapun kriteria inklusi subyek penelitian adalah pernah melakukan hubungan seksual dengan laki-laki, bekerja sebagai Waria Pekerja Seks, berdomisili di kota Makassar, terdata dalam pelaporan penjangkau lapangan LSM Yayasan Gaya Celebes, memiliki kejelasan alamat yang dapat terindentifikasi serta dapat ditemui di wilayah kota Makassar pada saat penelitian berlangsung, dapat berkomunikasi dengan baik,bersedia menjadi responden yang dibuktikan dengan penandatangan lembar persetujuan (informed consent).Kriteria ekslusi subyek penelitian adalahsedang tidak berada di kota Makassar pada saat penelitian dilakukan, responden yang mengalami HIV AIDS Opportunistik, tidak bersedia menjadi responden.

\section{HASIL PENELITIAN}

\section{Hasil Analisis Kuantitatif}

Persepsi manfaat merupakan penilaian responden ketika memperoleh keuntungan dalam penggunaan kondom dan pelicin. Pengkategorian dibagi menjadi dua yaitu dikatakan buruk jika skor kurang dari mean atau median dan dikatakan baik jika skor lebih dari atau sama dengan mean atau median.

Hasil uji normalitas terhadap data peneliltian persepsi manfaat yang dirasakan terdistribusi tidak normal sehingga kategorinya menggunakan nilai median. Persepsi manfaat yang dirasakan responden buruk jika $<10$ dan manfaat yang dirasakan baik jika $\geq 10$.

Tabel 1 menunjukkan bahwa persepsi responden tentang manfaat yang dirasakan pada kategori kurang sebesar 18,3\%. Tabel 2 di atas, dari 60 responden yang diteliti menunjukkan bahwa masih ada responden yang memiliki persepsi manfaat yang dirasakan kurang baik dalam penelitian ini. Sebesar 98,3\% responden menyatakan tidak setuju terhadap pernyataan menggunakan kondom ketika 
berhubungan seks dengan pelanggan akan mengurangi risiko penularan HIV AIDS dan pernyataan setuju menggunakan kondom dengan beraneka rasa dapat menambah sensasi saat berhubungan seks sebesar $16,7 \%$.

Tabel 3 menunjukkan bahwa persentase responden yang tidak konsisten dalam penggunaan kondom masing-masing responden yang memiliki persepsi manfaat yang dirasakan kurang sebesar 50,0\%.

Hasil uji chi square didapatkan $p$ value $0,013<0,05$ yang artinya Ho ditolak sehingga ada hubungan yang bermakna antara variabel presepsi manfaat yang dirasakan dengan konsistensi penggunaan kondom.

\section{Hasil Analisis Kualitatif}

Berdasarkan hasil wawancara dengan informan utama mengenai persepsi tentang manfaat penggunaan kondom dan pelicin ketika berhubungan seks menunjukkan bahwa informan telah memiliki persepsi yang cukup baik dengan menyadari pentingnya penggunaan kondom dan pelicin disebabkan karena informan telah merasakan dampak dari berhubungan seks tanpa menggunakan kondom dan pelicin sehingga harus menderita HIV seperti sekarang ini. Berikut adalah pernyataan informan :

“...manfaatnya sy aman, tamunya jg aman. Sama dengan pelicin jg kan.
Kan kalau sudah pake kondom kan harus pake pelicin jg kalau ndk pake pelicin kan kondomnya mudah sobek dan kalau sobek kondomnya kan takutnya nnti tumpah spermanya itu sama saja ndk pake kondom kan."

34 tahun, Panaikang

Selain wawancara diatas, informan utama juga menyatakan bahwa pentingnya melakukan tes VCT untuk mengetahui kondisi kesehatannya. Hal ini menunjukkan bahwa informan menyadari pentingnya melakukan tes VCT untuk mengetahui status kesehatan mereka. Berikut adalah pernyataan informan :

“...ya penting sekali krn demi dirinya sendirinya kan kalau pengen sehat ya harus melakukan VCT."

34 tahun, Panaikang

\section{PEMBAHASAN}

Konsistensi Penggunaan Kondom pada Waria Pekerja Seks di Kota Makassar

Penelitian ini berfokus pada konsistensi penggunaan kondom pada Waria Pekerja Seks di kota Makassar. Konsistensi penggunaan kondom pada Waria Pekerja Seks terbagi menjadi dua kategori yaitu konsisten dan tidak konsisten. Perilaku merupakan keseluruhan (totalitas) pemahaman dan aktivitas seseorang yang merupakan hasil bersama antara faktor internal dan eksternal. Perilaku seseorang adalah sangat kompleks dan mempunyai bentangan yang sangat luas. Terdapat adanya 3 ranah atau domain dari perilaku 
yakni kognitif (cognitive), affektif (affective) dan psikomotor (psychomotor). Oleh para ahli pendidikan di Indonesia, ketiga domain ini diterjemahkan menjadi cipta (kognitif), rasa (afektif) dan karsa/ tindak (psikomotor).

Berdasarkan hasil penelitian pelanggan.

Hasil penelitian kualitatif dengan Waria Pekerja Seks yang positif HIV menjelaskan bahwa informan rutin menggunakan kondom dan pelicin ketika melayani pelanggan. Terakhir kali informan melayani pelanggan adalah 3

Tabel 2. Distribusi Frekuensi Rincian Jawaban Persepsi Manfaat yang Dirasakan

\begin{tabular}{|c|c|c|c|c|c|}
\hline \multirow{2}{*}{ Pernyataan } & \multirow{2}{*}{$\mathrm{F}$} & \multicolumn{2}{|r|}{$\mathrm{S}$} & \multicolumn{2}{|r|}{$\mathrm{TS}$} \\
\hline & & $\mathrm{n}$ & $\%$ & $\mathrm{n}$ & $\%$ \\
\hline $\begin{array}{l}\text { Saya dapat mengetahui status } \\
\text { HIV saya dengan melakukan tes } \\
\text { HIV }\end{array}$ & 60 & 57 & 95,0 & 3 & 5,0 \\
\hline $\begin{array}{l}\text { Menggunakan kondom ketika } \\
\text { berhubungan seks dengan } \\
\text { pelanggan akan mengurangi } \\
\text { risiko penularan HIV AIDS }\end{array}$ & 60 & 59 & 98,3 & 1 & 1,7 \\
\hline $\begin{array}{l}\text { Penggunaan pelicin saat anal } \\
\text { dan oral seks akan mengurangi } \\
\text { risiko penularan HIVAIDS }\end{array}$ & 60 & 54 & 90,0 & 6 & 10,0 \\
\hline $\begin{array}{l}\text { Saya merasa lebih aman jika } \\
\text { menggunakan kondom saat } \\
\text { berhubungan seks }\end{array}$ & 60 & 54 & 90,0 & 6 & 10,0 \\
\hline $\begin{array}{l}\text { Menggunakan kondom dengan } \\
\text { beraneka rasa dapat menambah } \\
\text { sensasi saat berhubungan seks }\end{array}$ & 60 & 50 & 83,3 & 10 & 16,7 \\
\hline
\end{tabular}

Sumber: Data Primer, 2018

menunjukkan bahwa dari 60 responden terdapat 10 responden yang tidak konsisten dalam penggunaan kondom dan pelicin $(16,7 \%)$ dan 50 responden $(83,3 \%)$ konsisten dalam penggunaan kondom dan pelicin selama 2 bulan terakhir setiap melakukan hubungan seks dengan bulan yang lalu. Informan juga menjelaskan bahwa penggunaan pelicin hanya pada saat melakukan hubungan seks melalui anal.

Sedangkan, hasil wawancara mendalam dengan informan triangulasi diperoleh hasil bahwa pada kenyataannya, 
Waria Pekerja Seks telah mendapatkan dukungan dan perhatian yang cukup dari petugas LSM Gaya Celebes. Hal ini didukung rutinitas petugas lapangan untuk membagikan kondom dan pelicin secara gratis kepada komunitas Waria Pekerja Seks ratio 4,974. Konsistensi pemakaian kondom terhadap penyakit infeksi menular seksual servisitis non spesifik juga terdapat hubungan yang bermakna, dimana sebanyak $25,9 \%$ terkena infeksi menular seksual servisitis non spesifik dengan relative ratio

Tabel 3. Hubungan Persepsi Manfaat yang Dirasakan dengan Konsistensi Penggunaan Kondom

\begin{tabular}{llclll}
\hline & \multicolumn{3}{c}{ Konsistensi Penggunaan Kondom } & & \multirow{2}{*}{ P Value } \\
\cline { 2 - 5 } $\begin{array}{l}\text { Presepsi Manfaat yang } \\
\text { dirasakan }\end{array}$ & \multicolumn{2}{c}{ Tidak Konsisten } & \multicolumn{2}{c}{ Konsisten } & \\
\cline { 2 - 5 } & $\mathrm{f}$ & $\%$ & $\mathrm{f}$ & $\%$ & \\
\hline Kurang & 5 & 50,0 & 6 & 12,0 & 0,013 \\
Baik & 5 & 50,0 & 44 & 88,0 & \\
Total & 10 & 16,7 & 50 & 83,3 & \\
\hline
\end{tabular}

Sumber: Data Primer, 2018

yang berada di hospot dan rutin mengadakan penyuluhan dan mobile VCT sehingga upaya yang perlu dilakukan saat ini adalah peningkatan motivasai bagi komunitas Waria dengan fasilitas yang telah diberikan.

Penelitian sejalan dilakukan oleh Dameria Ginting menunjukkan bahwa tingkat konsistensi pemakaian kondom oleh WPS adalah 41,5\%. Terdapat hubungan yang bermakna antara konsistensi pemakaian kondom terhadap kejadian penyakit infeksi menular seksual gonore, dimana sebanyak $11,1 \%$ terkena infeksi menular seksual gonore dengan relative
2,538. Dan konsistensi pemakaian kondom terhadap kejadian penyakit infeksi menular seksual trikomoniasis juga terdapat hubungan yang bermakna, dimana sebanyak $7,4 \%$ terkena infeksi menular seksual trikomoniasis dengan relative ratio 7,641 . (Ginting,2016)

Variabel yang Berhubungan dengan Konsistensi Penggunaan Kondom

Persepsi manfaat yang dirasakan (Perceived Benefits) adalah persepsi responden penilaian individu ketika memperoleh keuntungan dalam menggunakan kondom dan pelicin sebagai upaya pencegahan penularan HIV AIDS. 
Menurut teori Health Belief Model (HBM) bahwa persepsi manfaat merupakan pendapat seseorang mengenai fungsi terhadap perilaku baru untuk mengurangi risiko perkembangan suatu penyakit. Seseorang yang hidup dengan menerapkan pola hidup yang sehat tidak akan mudah terserang oleh penyakit. Manfaat yang dirasakan akan memberikan pengaruh yang kuat untuk berperilaku hidup sehat dan menekan risiko terjadinya penyakit. (Notoatmodjo,2012)

Hasil uji statistic chi square diperoleh nilai $p$ value $0,013(\mathrm{p}<0,05)$ yang berarti bahwa ada hubungan yang signifikan antara persepsi manfaat yang dirasakan dengan konsistensi penggunaan kondom. Kenyataan di lapangan menyatakan bahwa persepsi informan megnenai manfaat penggunaan kondom dan pelicin dapat mengurangi risiko penularan IMS dan HIV AIDS namun, kebutuhan ekonomi dan seksual tidak mampu membuat responen untuk tetap konsisten menggunakan kondom dan pelicin ketika melakukan hubungan seks dengan pasangan tetap dan pelanggan.

Hasil penelitian kualitatif menjelaskan bahwa informan Waria Pekerja Seks yang positif HIV telah memiliki persespi yang cukup baik mengenai manfaat penggunaan kondom dan pelicin disebabkan karena informan telah merasakan dampak yang dialami ketika berhubungan seks dengan bergantiganti pasangan tanpa menggunakan kondom dan pelicin.

Analisis statistic penelitian ini sejalan dengan penelitian yang telah dilakukan oleh Ika Hapsari yang menyatakan bahwa ada hubungan antara persepsi manfaat dengan perilaku pencegahan penularan HIV/ AIDS pada Waria Pekerja Seks di kabupaten Kudus dengan nilai $p$ value $=0,001$. (Enggarwati,2015). Penelitian yang dilakukan Xianhong Li juga sejalan dengan penelitian di atas yang mengemukakan bahwa informan mengetahui engan jelas manfaat dari perilaku seks yang aman melalui penggunaan kondom yang konsisten dapat mencegah penularan HIV AIDS. Informan akan terus mempertahankan perilaku seks yang aman agar dapat bertanggung jawab pada kesehatan keluarganya.(Xianhong,2016)

\section{KESIMPULAN}

Penelitian ini menjelaskan bahwa informan yang berstatus HIV disebabkan karena seringnya berganti-ganti pasangan seks tanpa menggunakan kondom dan pelicin namun seteleh mengetahui statusnya HIV, informan lebih 
memperhatikan kesehatannya dengan konsisten menggunakan kondom dan pelicin setiap berhubungan seks dengan pasangan tetap dan pelanggan agar tidak membahayakan dan menularkan pada orang lain. Namun, sebagian besar pelanggan tidak bersedia untuk menggunakan kondom saat berhubungan seks karena merasa tidak nyaman dan tidak puas jika menggunakan kondom sehingga informan harus meyakinkan pelanggan agar mau menggunakan kondom agar terhindar dari IMS dan HIV AIDS dan apabila upaya tersebut tidak berhasil maka informan akan menolak melayani pelanggan tersebut walau dengan bayaran yang lebih besar.

\section{SARAN}

Setelah mengetahui faktor yang berhubungan dengan konsistensi penggunaan kondom tersebut, maka perlu adanya pengadaan penyuluhan kesehatan terkait dengan konsistensi penggunaan kondom secara persuasive, edukatif, dan komunikatif kepada komunitas Waria Pekerja Seks secara intens dan berkesinambungan agar Waria Pekerja Seks dapat lebih mengerti dan memahami konsistensi penggunaan kondom secara medis.

Adanya penjangkauan bagi Waria Pekerja Seks yang bekerja melalui media social untuk memperoleh pelanggan agar tetap memastikan persediaan kondom dan pelicin bagi Waria Pekerja Seks yang mencari pelanggan melalui online (social media) maupun berada di lokalisasi.

Peningkatan kerjasama dalam hal pencatatan dan pelaporan kasus IMS dan HIV AIDS pada Waria Pekerja Seks dengan pihak KPA (Komisi Penanggulangan AIDS) kota Makassar.

Komunitas Waria Pekerja Seks diharapkan lebih meningkatkan kesadaran dan kepedulian terhadap penggunaan kondom dan pelicin secara konsisten dalam mencegah dan mengurangi kejadian IMS dan HIV AIDS serta melakukan pemeriksaan diri terkait penyakit IMS maupun HIV di klinik layanan kesehatan yang tersedia.

Masyarakat diharapkan berperan aktif dalam peningkatan pengetahuan serta penyebaran informasi mengenai IMS dan HIV AIDS serta konsistensi dalam penggunaan kondom dan pelicin,

Pada penelitian ini, kami mengharapkan agar peneliti berikutnya dapat mengembangkan dan mengintervensi konsistensi penggunaan kondom agar lebih efektif dan aplikatif.

\section{DAFTAR PUSTAKA}

Demartoto A. 2011. Perilaku Seksual MSM (Men Who Have Sex With Men) dalam kaitannya dengan HIV AIDS. Lemb Swadaya Masy Gessang. 
Dinas Kesehatan Kota Makassar. 2017. Profil Kesehatan Kota Makassar. Dinas Kesehatan Kota Makassar. Makassar.

Enggarwati Eka. 2015. Faktor-Faktor yang Berhubungan dengan Perilaku Pencegahan Penularan HIV / AIDS pada Waria Pekerja Seks Di Kabupaten Kudus Tahun

Koeswinarno. 2014. Epidemiologi Penyakit Menular dan Tidak Menular. Bandung: Alfabeta.

LSM YPKDS. 2017. Surveilans KPAP Sulawesi Selatan.

Mutmainnah Faidah. 2013. Religiusitas dan Konsep Diri Kaum Waria.

Nadhofah I.. 2014. Faktor-faktor yang mempengaruhi niat waria untuk menggunakan kondom dan pelicin dalam berhubungan seksual untuk mencegah penularan HIVIAIDS di kabupaten Kendal. Universitas
Diponegoro.

Notoatmodjo S. 2012. Promosi Kesehatan dan Ilmu Perilaku. Jakarta: Rineka Cipta.

Ridwan A. 2013. Modul Surveilans HIV dan AIDS. Jakarta: Komisi Penanggulangan AIDS Nasional.

Sugiyono Dr. Prof. 2014. Metode Penelitian Kualitatif, Kuantitatif, Dan Kombinasi (Mixed Methods). Bandung: Alfabeta.

UNAIDS/ WHO. 2016. Guidelines for second generation HIV Survailance. UNAIDS/ WHO.

Xianhong L, Yunxiao L, Wang H, Guoping. 2016. The Health Belief Model: A Qualitative Study to Understand High-Risk Sexual Behavior in Chinese Men Who Have Sex With Men. Pubmed. 27 (1):66-76. 